\title{
Analisis Persediaan Bahan Bau Produksi Beton dengan Metode Material Requirement Planning (MRP) pada PT. Merak Jaya Beton Plant Kedung Cowek Surabaya
}

\author{
Nurul Chamidah, \\ Universitas Airlangga \\ T. Aria Auliandri \\ Universitas Airlangga \\ aria@feb.unair.ac.id
}

\begin{abstract}
Abstraksi
Persediaan merupakan hal yang paling krusial di perusahaan, baik manufaktur maupun jasa. Tidak sedikit kemungkinan banyak masalah yang timbul disuatu perusahaan mengenai persediaan bahan baku nya. Dari mulai kelebihan bahan baku hingga kekurangan bahan baku. Metode MRP merupakan salah satu metode untuk pengendalian persediaan bahan baku. Dengan metode MRP diharap persediaan bahan baku disuatu perusahaan lebih terkontrol. PT. Merak Jaya Beton merupakan salah satu perusahaan beton di Surabaya dimana operasional perusahaan ini sangat bergantung pada persediaan bahan bakunya. Mengingat bahwa bahan baku beton berasal dari sumber daya alam yang stoknya sulit untuk diprediksi sehingga perusahaan sering melakukan penumpukan bahan baku sehingga perusahaan mengeluarkan biaya yang sangat besar. Dengan menerapkan metode MRP berdasarkan pendekatan FPR didapatkan hasil pengeluaran biaya terendah dibanding dengan metode EOQ, FOQ dan metode perusahaan.
\end{abstract}

Kata kunci: Pengendalian Persediaan, Metode MRP, Metode Lot sizing

\section{Pendahuluan}

Persediaan (inventory) merupakan suatu aset yang ada dalam bentuk barang-barang yang dimiliki untuk dijual dalam operasi perusahaan maupun barang-barang yang sedang didalam proses pembuatan (work in process). Berdasarkan pengertian persediaan secara umum dapat dikatakan bahwa persediaan merupakan aset yang berharga bagi perusahaan manufaktur maupun jasa. Menurut pendapat Indrajit dan Djokopranoto (2003), nilai investasi perusahaan dalam bentuk persediaan sebesar 25\%-35\% dari nilai seluruh aset. Jadi persediaan merupakan investasi terbesar dalam perusahaan, maka dari itu perusahaan harus dapat mengendalikan persediaan seefisien dan seefektif mungkin supaya dapat mencapai biaya persediaan yang optimal. Salah satu metode pengendalian persediaan adalah material requirement planning (MRP). Menurut Astana MRP merupakan konsep dalam manaemen produksi yang membahas cara yang tepat dalam perencanaan kebutuhan barang dalam proses produksi, sehingga barang yang dibutuhkan dapat tersedia sesuai dengan rencana. Diharapkan setelah menerapkan MRP perusahan bisa menjalankan manajemen produksi dengan baik dan rapi.

Untuk menunjang penelitian ini, penulis melakukan penelitian di PT. Merak Jaya Beton Plant Kedung Cowek Surabaya. Perusahaan ini menghasilkan produk beton ready mix. 
Dalam kegiatan produksi PT. Merak Jaya Beton Plant Kedung Cowek Surabaya yaitu melakukan produksi ketika ada pesanan dari pelanggan saja (make to order). sejauh ini perusahaan belum melakukan majemen persediaan dengan baik. MRP dapat membantu perusahaan melakukan perencanaan penjadwalan produksi dan perencanaan pembelian bahan baku kepada supplier. Diharapkan perusahaan lebih efisien dalam melakukan manajemen persediaan.

\section{Landasan Teori}

Menurut pendapat Assauri (1993), persediaan adalah suatu aktiva yang meliputi barang-barang milik perusahaan dengan maksud untuk dijual dalam suatu periode usaha yang normal, atau persediaan barang-barang yang masih dalam pengerjaan/proses produksi, ataupun persediaan bahan baku yang menunggu penggunaannya dalam suatu proses produksi, jadi merupakan sejumlah bahan-bahan yang disediakan untuk memenuhi permintaan pelanggan.

Jenis-jenis persediaan menurut Pujawan dan Mahendra (2010: 119-121) yaitu:

1. Bahan baku

2. $\quad$ Barang setengah jadi

3. Produk jadi

Sedangkan tujuan persediaan menurut Slack (2013: 372-373) yaitu:

1. Persediaan membantu perusahaan menghadapi ketidakpastian

2. Persediaan memungkinkan perusahaan menjadi lebih fleksibel

3. Persediaan memungkinkan perusahaan mendapatkan keuntungan dalam jangka waktu tertentu

4. Persediaan dapat mengantisipasi permintaan yang akan datang

5. Nilai persediaan dapat meningkat dari waktu ke waktu

Pada umumnya ketika perusahaan menyimpan persediaan maka perusahaan harus mengeluarkan biaya-biaya persediaan. Biaya-biaya persediaan menurut Rangkuti (2002) yaitu:

1. Biaya penyimpanan (holding cost/carrying cost), biaya ini dikeluarkan ketika perusahaan menyimpan persediaannya.

2. Biaya pemesanan (ordering cost/procurement cost), biaya ini dikeluarkan ketika perusahaan melakukan pemesanan bahan baku ke supplier atau biaya pengadaan bahan baku.

Untuk mencapai efisiensi dan efektifitas biaya-biaya persediaan, maka perusahaan harus tepat dalam melakukan pengendalian persediaan bahan baku. MRP adalah metode yang dipilih dalam penelitian ini dalam melakukan pengendalian persediaan bahan baku. Sesuai dengan pengertian MRP menurut Astana (2007), adalah suatu rencana dalam manajemen produksi yang membahas cara yang tepat dalam perencanaan kebutuhan barang dalam proses produksi, sehingga barang yang dibutuhkan oleh perusahaan dapat tersedia sesuai dengan yang telah direncanakan. Dalam menerapkan MRP hal mendasar yang diperlukan dalam menyusun MRP menurut Nasution (2013:136) yaitu: 
1. Master Production Schedule (MPS), yaitu jadwa utama yang digunakan perusahaan dalam memenuhi permintaan pelanggan.

2. Inventory Status Record, yaitu informasi mengenai rekapan bahan baku yang tersedia dalam perusahaan.

3. Bill of Material (BOM), yaitu data struktur produk yang detail dengan komponenkomponen pernyusannya.

Lot sizing menurut pendapat Chase et, al (2006), yaitu komponen yang dikeluarkan pada rencana penerimaan order dan pengeluaran order pada jadwal MRP. Dalam penelitian ini menggunakan 3 teknik lot sizing yaitu:

1. Economic Quantity Order (EOQ), pada teknik ini ukuran didapat atas dasar meminimasi biaya simpan dan biaya pesan. Ukuran lot tetap berdasarka hitungan minimasi tersebut.

EOQ: $\sqrt{\frac{2 D k}{h}}$

2. $\quad$ Fixed Order Quantity (FOQ), pada teknik ini ukuran lot didapat berdasarkan intuisi dari manajer berdasarkan pengalaman-pengalaman sebelumnya. Ukuran lot selalu tetap, namun peride pemesanan selalu berubah.

3. $\quad$ Fixed Period Requirement (FPR), pada teknik ini ukuran lot didapatkan berdasarkan akumulasi kebutuhan bahan baku atas beberapa periode, sedangkan periode pemesanan ditetapkan berdasarkan intuisi manajer dan periode pemesanan tetap.

\section{Metodologi Penelitian}

Menurut Zulian Yamit (2005), tahap proses pengolahan MRP terbagi menjadi netting, Lotting, offsetting, explosion. Pada penelitian di PT. Merak Jaya Beton Plant Kedung Cowek, sistem operasinal produksi perusahaan berdasarkan make to order, jadi jumlah permintaan yang dipesan pelanggan dengan jumlah jadwal produksi besarnya sama. Penelitian ini menggunakan 3 teknik lotting, yaitu EOQ, FOQ dan FPR. Setelah dilakukan lotting maka dihitung biaya-biaya persediaan berdasarkan ketiga teknik lot sizing tersebut. Setelah itu, biaya-biaya yang dihasilkan dari proses lotting tersebut di bandingkan kemudian disimpulkan. Teknis analisis yang digunakan dalam penelitian ini yaitu:

1. Menghitung permintaan beton mutu K300 pada tahun 2015

2. Menyusun BOM pada batch card K300

3. Menghitung kebutuhan kotor pada masing-masing bahanbaku pada tahun 2015

4. Menentukan jumlah pembelian yang optimal berdasarkan metode MRP dengan pendekatan EOQ, FOQ dan FPR

5. Menghitung biaya-biaya persediaan antara metode yang digunakan perusahaan dengan metode MRP pendekatan EOQ, FOQ dan FPR

6. Membandingkan biaya-biaya yang dihasilkan berdasarkan metode perusahaan dengan ketiga metode lot sizing

\section{Hasil dan Pembahasan}

PT. Merak Jaya Beton merupakan salah satu perusahaan beton yang berada di Surabaya. Pada penelitian ini dilakukan di PT. Merak Jaya Beton Plant Kedung Cowek 
Surabaya. Produk yang dihasilkan yaitu beton readymix. Berikut adalah komponen dalam penerapan MRP:

1. Inventory status record pada awal tahun 2015

Tabel 1. Inventory Status Record pada bahan baku produksi beton pada awal tahun 2015

\begin{tabular}{|c|c|c|}
\hline No. & Item & Persediaan \\
\hline 1 & Semen & 318.6 ton \\
\hline 2 & Fly Ash & 90.13 ton \\
\hline 3 & Pasir & $2,802.23 \mathrm{~m} 3$ \\
\hline 4 & Split $5-15$ & $671.75 \mathrm{~m} 3$ \\
\hline 5 & Split $1-2$ & $1,498.88 \mathrm{~m} 3$ \\
\hline 6 & Pozzolith & 1,356 liter \\
\hline 7 & Polliheed & 2,870 liter \\
\hline
\end{tabular}

\section{Bill of Material (BOM)}

Dalam $1 \mathrm{~m} 3$ beton berdasarkan mutu K300 membutuhkan proporsi bahan baku sebagai berikut:
a. Semen $225 \mathrm{~kg}$
b. Fly ash $105 \mathrm{~kg}$
c. Pasir $781 \mathrm{~kg}$
d. Split $5-15225 \mathrm{~kg}$
e. Split $1-2900 \mathrm{~kg}$
f. Pozzolith 0,49 liter
g. Polliheed 1,98 liter
h. Air 170 liter
3. Master Production Schedule (MPS)

Tabel 2. Master Production Schedule pada Tahun 2015

\begin{tabular}{|c|c|c|}
\hline NO & BULAN & $\begin{array}{c}\text { JUMLAH VOL. } \\
\text { PRODUKSI }\end{array}$ \\
\hline 1 & Januari & 3,415 \\
\hline 2 & Februari & 3,057 \\
\hline 3 & Maret & 2,762 \\
\hline 4 & April & 3,308 \\
\hline 5 & Mei & 4,024 \\
\hline 6 & Juni & 4,876 \\
\hline 7 & Juli & $2,879.5$ \\
\hline 8 & Agustus & $4,355.5$ \\
\hline 9 & September & $3,194.5$ \\
\hline 10 & Oktober & $3,745.5$ \\
\hline 11 & November & 3,846 \\
\hline 12 & Desember & $3,265.5$ \\
\hline \multicolumn{2}{|c|}{ Total } & $42,728.5$ \\
\hline
\end{tabular}


Setelah mengetahui 3 komponen input MRP diatas, dapat ditentukan outout dari MRP. Dalam menerapkan MRP hal pertama yang harus dilakukan yaitu dengan menentukan kebutuhan bersih. Pada perusahaan ini menerapkan sistem make to order, jadi jumlah kebutuhan bahan baku sama dengan jumlah pesanan yang diminta pelanggan. Kebutuhan bersih didapat dari kebutuhan kotor dikurangi dengan persediaan ditangan. Berikut adalah kebutuhan bersih bahan baku semen:

Tabel 3. Kebutuhan Bersih Bahan Baku

\begin{tabular}{|l|r|r|r|r|r|r|r|}
\hline Item/Periode (week) & $\mathbf{1}$ & $\mathbf{2}$ & $\mathbf{3}$ & $\mathbf{4}$ & $\mathbf{5}$ & $\mathbf{6}$ & $\mathbf{7}$ \\
\hline Gross Requirement & 9 & 106.99 & 130.5 & 203.74 & 182.48 & 171.7 & 182.14 \\
\hline On Hand = 318 & 309 & 202.01 & 71.513 & -132.23 & -314.7 & 486.4 & -668.5 \\
\hline Net Requirement & & & & 132.23 & 182.48 & 171.7 & 182.14 \\
\hline Planned Order Receipt & & & & 132.23 & 182.48 & 171.7 & 182.14 \\
\hline Planned Order Release & & & & 132.23 & 182.48 & 171.7 & 182.14 \\
\hline
\end{tabular}

Setelah kebutuhan bahan baku bersih diketahui maka langkah selanjutnya yaitu menentukan ukuran lot berdasarkan 3 metode pendekatan:

\section{Economic Order Quanity (EOQ)}

Dalam teknik EOQ ini yaitu dalam menentukan lot dengan mempertimbangkan biayabiaya persediaan, misalnya biaya pemesanan dan biaya penyimpanan. Ukuran lot tetap.

EOQ $=\sqrt{\frac{2 D k}{h}}=\sqrt{\frac{2 \times 11.650 \text { tonxRp.283.000,- }}{R p .16 .250,-}}=637$ ton/mingguan, sehingga untuk harian sebesar 91 ton/harian.

Tabel 4. Perhitungan dengan menggunakan pendekatan EOQ pada bahan baku semen dari minggu 1 sampai 7 pada tahun 2015

\begin{tabular}{|l|r|r|r|r|r|r|r|}
\hline Item/Period (week) & $\mathbf{1}$ & $\mathbf{2}$ & $\mathbf{3}$ & $\mathbf{4}$ & $\mathbf{5}$ & $\mathbf{6}$ & $\mathbf{7}$ \\
\hline Net Requirement & 0 & 0 & 0 & 132.2 & 182.48 & 171.68 & 182.1 \\
\hline Lot Sizing & 0 & 0 & 0 & 637 & & & 637 \\
\hline Final Inventory & 0 & 0 & 0 & 505 & 322 & 151 & 605 \\
\hline
\end{tabular}

\section{Fixed Order Quantity (FOQ)}

Pada teknik ini ukuran lot ditentukan berdasarkan intuisi dari manajer berdasarkan pengalaman-pengalaman sebelumnya. Ukuran lot pada teknik FOQ ini tetap, namun periode pemesanannya yang berubah. Besar ukuran lot pada bahan baku semen berdasarkan metode FOQ yaitu sebesar 600 ton dalam sekali order dalam periode mingguan, maka untuk ukuran lot pendekatan FOQ sebesar 86 ton/harian. 
Tabel 5. Perhitungan dengan menggunakan pendekatan FOQ pada bahan baku semen dari minggu 1 sampai 7 pada tahun 2015

\begin{tabular}{|l|r|r|r|r|r|r|r|}
\hline Item/Period (week) & $\mathbf{1}$ & $\mathbf{2}$ & $\mathbf{3}$ & $\mathbf{4}$ & $\mathbf{5}$ & $\mathbf{6}$ & $\mathbf{7}$ \\
\hline Net Requirement & 0 & 0 & 0 & 132.23 & 182.5 & 171.7 & 182.14 \\
\hline Lot Sizing & 0 & 0 & 0 & 600 & & & 600 \\
\hline Final Inventory & 0 & 0 & 0 & 468 & 285 & 114 & 531 \\
\hline
\end{tabular}

\section{Fixed Period Requirement (FPR)}

Pada teknik FPR ini ukuran lot didapatkan dari akumulasi kebutuhan dalam beberapa periode, jadi ukuran lot selalu berubah. Namun periode pemesanan tetep, sedangkan periode pemesanan didapatkan dari intuisi manajer berdasarkan pengalaman sebelumnya. Besar ukuran lot pada bahan baku semen berdasarkan metode FPR yaitu sebesar akumulasi kebutuhan 4 periode berjalan dimana besar kebutuhannya selalu berubah-ubah.

Tabel 6. Perhitungan dengan menggunakan pendekatan FPR pada bahan baku semen dari minggu 1 sampai 7 pada tahun 2015

\begin{tabular}{|l|r|r|r|r|r|r|r|}
\hline Item/Period (week) & $\mathbf{1}$ & $\mathbf{2}$ & $\mathbf{3}$ & $\mathbf{4}$ & $\mathbf{5}$ & $\mathbf{6}$ & $\mathbf{7}$ \\
\hline Net Requirement & 0 & 0 & 0 & 132.23 & 182.48 & 171.7 & 182.14 \\
\hline Lot Sizing & 0 & 0 & 0 & 668.52 & & & \\
\hline Final Inventory & 0 & 0 & 0 & 536 & 354 & 182 & 0 \\
\hline
\end{tabular}

Setelah dilakukan perhitungan lot maka langkah selanjutnya yang dilakukan yaitu perhitungan biaya-biaya persediaan berdasarkan 3 teknik lot sizing tersebut. Berikut adalah hasil perhitungan biaya-biaya persediaan berdasarkan metode yang digunakan perusahaan selama ini dengan metode MRP berdasarkan 3 teknik lot sizing.

Tabel 7. Perhitungan biaya-biaya persediaan berdasarkan metode perusahaan, metode EOQ, FOQ dan FPR pada tahun 2015

\begin{tabular}{|c|c|c|c|c|c|}
\hline \multirow{2}{*}{$\begin{array}{c}\text { Bahan } \\
\text { Baku }\end{array}$} & Uraian & \multicolumn{4}{|c|}{ Biaya-biaya Persediaan (Rp) } \\
\cline { 3 - 6 } & $\begin{array}{c}\text { Metode } \\
\text { Perusahaan }\end{array}$ & Metode EOQ & Metode FOQ & Metode FPR \\
\hline \multirow{3}{*}{ Semen } & Biaya Pemesanan & 60.562 .000 & 32.262 .000 & 33.960 .000 & 25.470 .000 \\
\cline { 2 - 6 } & Biaya Penyimpanan & 519.113 .400 & 263.461 .250 & 248.381 .250 & 260.487 .500 \\
\cline { 2 - 6 } & Total Biaya & 579.675 .400 & 295.723 .250 & 282.341 .250 & 285.957 .500 \\
\hline \multirow{3}{*}{ Fly Ash } & Biaya Pemesanan & 28.968 .000 & 11.016 .000 & 24.480 .000 & 22.032 .000 \\
\cline { 2 - 6 } & Biaya Penyimpanan & 73.540 .000 & 94.775 .000 & 32.670 .000 & 38.960 .000 \\
\cline { 2 - 6 } & Total Biaya & 102.508 .800 & 105.791 .000 & 57.150 .000 & 60.992 .000 \\
\hline \multirow{3}{*}{ Pasir } & Biaya Pemesanan & 73.848 .000 & 24.480 .000 & 41.616 .000 & 44.064 .000 \\
\cline { 2 - 6 } & Biaya Penyimpanan & 181.665 .000 & 172.015 .003 & 92.855 .630 & 85.544 .358 \\
\cline { 2 - 6 } & Total Biaya & 255.513 .000 & 196.495 .003 & 134.471 .630 & 129.608 .358 \\
\hline \multirow{2}{*}{ Split5- } & Biaya Pemesanan & 44.520 .000 & 13.440 .000 & 20.160 .000 & 13.440 .000 \\
\cline { 2 - 6 } 15 & Biaya Penyimpanan & 52.185 .000 & 39.283 .352 & 22.698 .312 & 24.402 .704 \\
\cline { 2 - 6 } & Total Biaya & 96.705 .000 & 52.723 .352 & 42.858 .312 & 37.842 .764 \\
\hline
\end{tabular}


Nurul Chamidah, T.Aria Auliandri

\begin{tabular}{|c|c|c|c|c|c|}
\multirow{4}{*}{ Split 1-2 } & Biaya Pemesanan & 70.000 .000 & 18.480 .000 & 25.200 .000 & 21.840 .000 \\
\cline { 2 - 6 } & Biaya Penyimpanan & 149.850 .000 & 156.996 .360 & 113.672 .385 & 123.708 .492 \\
\cline { 2 - 6 } & Total Biaya & 219.850 .000 & 175.116 .360 & 138.872 .385 & 145.548 .492 \\
\hline \multirow{3}{*}{ Pozzolith } & Biaya Pemesanan & 3.810 .000 & 1.524 .000 & 4.318 .000 & 3.048 .000 \\
\cline { 2 - 6 } & Biaya Penyimpanan & 54.070 .200 & 69.626 .775 & 22.716 .879 & 23.867 .086 \\
\cline { 2 - 6 } & Total Biaya & 57.880 .200 & 71.150 .775 & 27.034 .879 & 26.915 .086 \\
\hline \multirow{3}{*}{ Polliheed } & Biaya Pemesanan & 7.366 .000 & 2.540 .000 & 3.810 .000 & 3.302 .000 \\
\cline { 2 - 6 } & Biaya Penyimpanan & 124.695 .000 & 155.092 .031 & 78.469 .797 & 67.089 .043 \\
\cline { 2 - 6 } & Total Biaya & 132.061 .000 & 157.632 .031 & 82.279 .797 & 70.391 .643 \\
\hline \multicolumn{2}{|c|}{ Total } & $\mathbf{1 . 4 4 4 . 1 9 3 . 4 0 0}$ & $\mathbf{1 . 0 5 4 . 6 3 1 . 7 7 1}$ & $\mathbf{7 6 5 . 0 0 8 . 2 5 3}$ & $\mathbf{7 5 7 . 2 5 5 . 8 4 3}$ \\
\hline
\end{tabular}

Perhitungan biaya-biaya persediaan berdasarkan 2 jenis biaya, yaitu biaya pemesanan dan biaya penyimpaan. Biaya pemesanan didapatkan dari biaya yan dikeluarkan saat melakukan pengadaan bahan baku, misalnya biaya trasnportasi, biaya supir, biaya kuli, dll. Sedangkan biaya penyimpanan didapatkan dari biaya-biaya yang mungkin dikeluarkan ketika perusahaan melakukan penyimpanan bahan baku digudang, misalnya biaya fasilitas, biaya kerusahakan bahan baku dan biaya perawatan mesin. Berdasarkan tabel perhitunngan biayabiaya persediaan yang dihasilkan dapat dilihat bahwa total biaya persediaan yang perusahaan keluarkan selama tahun 2015 sebesar Rp. 1.444.193.400,-, dapat dikatakan bahwa biaya yang dikeluarkan perusahaan sangat tinggi dibandingkan dengan metode MRP teknik EOQ sebesar 1.054.631.771,-, teknik FOQ sebesar Rp.765.008.253,- atau dan teknik FPR Rp. 757.255.843,-. Selisih yang disebabkan oleh 2 hal, yaitu tingkat pemesanan yang lebih rendah pada metode MRP dibanding dengan metode yang perusahaan pakai, selain itu dengan mengubah pola mingguan sehingga meminimalisir biaya simpan bahan baku dari bulanan menjadi mingguan.

\section{Simpulan dan Saran}

Berdasarkan pembahasan pada penelitian diatas, menghasilkan kesimpulan bahwa dengan menerapkan MRP menggunakan metode Fixed Requirement Planning (FPR) menghasilkan total biaya persediaan yang kecil dibandingkan dengan metode perusahaan atau dengan metode MRP pendekatan EOQ dan FOQ. Karena pendektan FPR merupakan akumulasi dari kebutuhan bahan baku 4 periode dimana di akhir periode ke 4 selalu menghasilkan persediaan sebesar nol yang berarti bahwa pada periode akumulasi ke 4 perusahaan tidak memiliki persediaan. Sehingga dengan hal tersebut bisa meminimalisir biaya penyimpanan. Maka dari itu, metode MRP dengan pendekatan FPR dirasa layak untuk diterapkan dalam perusahaan karena menghasilkan total biaya persediaan yang paling rendah dibandingkan dengan metode-metode yang ada.

\section{Daftar Pustaka}

Assauri, S. 1993. Manajemen Produksi dan Operasi. Edisi Empat. Jakarta. Lembaga Penerbit Fakultas Ekonomi Universitas Indonesia.

Astana, I.N.Y. 2007. Perencanaan Persediaan Bahan Baku Berdasarkan Metode Material Requirement Planning (MRP). Jurnal Ilmiah Teknik Sipil, Vol. 11, No. 2, pp. 184194. 
Chandra, Harry P dan Harry Patmadjaja. 2001. Aplikasi MRP untuk Mengendalikan Investasi Pengadaaan Material pada PT. JHS Pilling System. Surabaya. Dimensi Teknik Sipil Vol 3 No. 1 ISSN 1410-9530.

Indrajit \& Djokopranoto. 2003. Tingkat Persentase Persediaan Pada Perusahaan (Online). di ambil pada wesite (http://beta.lecture.ub.ac.id/files/2014/01/s_pts_055243_chapter.pdf). diakses pada tanggal 17 September 2015 Pukul 02.57 WIB.

Koher, Eric. 2004. Pengertian Persediaan Secara Umum Menurut Para Ahli (Online). diambil pada website (http://elib.unikom.ac.id/files/disk1/466/jbptunikompp-gdl-linnaismaw23295-5-5manaje-n.pdf). diakses pada tanggal 22 September 2015 Pukul 15:13 WIB.

Nasution, Arman Hakim. 2008. Perencanaan dan Pengendalian Produksi. Yogyakarta. PT. Graha Ilmu.

Nawy. 1985. Pengertian Beton (Online). Diambil dari website (https://www.academia.edu/4554412/Pengertian Beton dan Sejarah Beton) diakses pada tanggal 14 Oktober 2015 pukul 07:40 WIB.

No Name. Pertumbuhan Penduduk Menjadi Beban Pemerintah (Online), diambil dari website (http://nasional.kompas.com/read/2014/01/29/1656015/Pertambahan.Jumlah.Pendudu k.Jadi.Beban.Pemerintah) diakses pada tanggal 18 September 2015 pukul 19:16 WIB.

No Name. 2014. Perkembangan Industri Beton di Indonesia (Online). diambil dari wesite (http://indonesian.irib.ir/international/asia-dan-pasifk/item/86590-indonesia-jadipasar-konstruksi-menguntungkan-di-asean) diakses pada tanggal 2 Oktober 2015 pukul 05:27 WIB.

Ranguti, Freddy. 2002. Biaya-biaya dalam Manajemen Persediaan. Jakarta. PT. Raja Grafindo.

Richard, Chase B. 2001. Operations Management for Competitive Advantage. New York. Mc Graw Hill. Co.Inc.

Sofwan, hadi. 2000. Sifat dan Kegunaan Fly Ash (Online). Diambil dari website (http://flyashjogja.blogspot.co.id/). Diakses pada tanggal 11 Desember 2015 pukul 14.19 WIB.

Sofyan, Dian Khairani. 2013. Perencanaan dan Pengendaliann Produksi Edisi Pertama. Yogyakarta. PT. Graha Ilmu.

Surnedi. 2010. Analisis manajemen persediaan dengan metode EOQ. Diambil dari website (eprints.uns.ac.id/3786/1/166320209201008581.pdf) Diakses pada tanggal 13 Oktober 2015 pukul 09:38 WIB.

Vialy, Jiant dan Ida Ayu Ari Angreni. 2013. Aplikasi Metode MRP terhadap Material Pasir, Semen dan Besi Tulangan pada Konstruksi Jalan Malang. Bandung. Proceeding PESAT.

Yulianto,Yosef Krisna Aris. 2013. Perencanaan Persediaan Bahan Baku Rokok Andalas SMild dengan Metode Time Series dan Metode Material Requirement Planning (MRP) pada Perusahaan Rokok Putera Maju Jaya. Surabaya. Ruang Baca FEB Unair. 